\title{
Effect of $\beta$-sitosterol on Insulin Receptor, Glucose Transporter 4 Protein Expression and Glucose Oxidation in the Gastrocnemius Muscle of High Fat Diet Induced Type -2 Diabetic Experimental Rats
}

\author{
Madhan Krishnan', Shyamaladevi Babu', Ponnulakshmi Rajagopal², Sohara Parveen Nazar, \\ Mayilvanan Chinnaiyan ${ }^{4}$, Selvaraj Jayaraman ${ }^{1, *}$ \\ ${ }^{1}$ Department of Biochemistry, Saveetha Dental College and Hospitals, Saveetha Institute of Medical and Technical Sciences, \\ Saveetha University, Chennai, Tamil Nadu, INDIA. \\ ${ }^{2}$ Central Research Laboratory, Meenakshi Academy of Higher Education and Research (Deemed to be University), Chennai, \\ Tamil Nadu, INDIA. \\ ${ }^{3}$ Department of Biochemistry, Faculty of Allied Health Sciences, Dr. M.G.R. Educational and Research Institute, Chennai, \\ Tamil Nadu, INDIA. \\ ${ }^{4}$ Department of Otolaryngology, University of Oklahoma Health Sciences Center, Oklahoma City, USA.
}

\begin{abstract}
Background: The newly available medications are ineffective because of their unintended side effects in the treatment of type 2 diabetes. Hence, search drugs, from plant sources. $\beta$-sitosterol is plant sterols with structurally almost like that of cholesterol. It is widely present in various medicinal plants. Although the sterol it was shown to possess antihyperglycemic activity, the mechanism of action of the plant sterol on a high-fat diet (HFD)-induced insulin resistance in gastrocnemius muscle is not yet determined. Objectives: To the assessment of the beneficial role of $\beta$-sitosterol on the expression of insulin-signaling molecules within the skeletal muscle of HFD-fed and sucrose-induced type- 2 diabetic rats. Materials and Methods: The effective oral $\beta$-sitosterol dose $120 \mathrm{mg} / \mathrm{kg}$ of body weight) was administered once daily until the conclusion of the research period. (30 days post-induction of diabetes) to HFD- fed diabetic rats. At the end of a period of experiment, fasting blood sugar (FBG), oral glucose (OGT) and tolerances (IT), Homeostasis Model Assessment for Insulin Resistance (HOMA-IR) and Quantitative Insulin Sensitivity Check Index (QUICKI), serum lipid profile, lipid peroxidation (LPO), peroxide $\left(\mathrm{H}_{2} \mathrm{O}_{2}\right)$ and hydroxyl $\left(\mathrm{OH}^{*}\right)$ generation, antioxidant enzymes as well as the levels of insulin signaling molecules like insulin receptor (IR), glucose transporter subtype 4 (GLUT4) proteins and glycogen concentration within the gastrocnemius muscle were assessed. Results: A diabetic rat indicates impaired tolerances for glucose and insulin and molecules signaling insulin (IR and GLUT4) proteins and glycogen concentration. In diabetic rats, serum insulin, lipid profile, $\mathrm{LPO}, \mathrm{H}_{2} \mathrm{O}_{2}, \mathrm{OH}^{*}$ has been found to be increased. The $\beta$-sitosterol treatment stabilized altered blood glucose levels, serum insulin levels, lipid profile, markers of oxidative stress, IR and GLUT4 protein levels. Conclusion: Our current findings suggest that $\beta$-sitosterol enhances Glycemic regulation in the gastrocnemius muscle by IR and GLUT4 activation of HFD- fed and sucrose-induced type- 2 diabetic rats.
\end{abstract}

Key words: $\beta$-sitosterol, IR, GLUT4, Glucose uptake and oxidation, Gastrocnemius muscle, High fat diet and sucrose, Type-2 diabetes, Insulin Signaling, Insulin resistance.

\section{INTRODUCTION}

Diabetes mellitus is related to abnormalities of carbohydrate, fat and protein metabolism, and characterized by abnormal serum insulin levels or insensitivity of target tissues to insulin action. ${ }^{1}$ Number of individuals with diabetes worldwide is 425 million
Submission Date: 22-08-2020; Revision Date: 25-11-2020; Accepted Date: 22-04-2021

DOI: 10.5530/ijper.55.2s.119 Correspondence:

Dr. Jayaraman Selvaraj Department of Biochemistry, Saveetha Dental College and Hospitals, Saveetha Institute of Medical and Technical Sciences, Saveetha University, Chennai-600 077, Tamil Nadu, INDIA. Phone no: +91-7397331154 Email id: jselvaendo@gmail. com 
in 2017 and it is estimated that the amount will reach around 629 million by $2045 .^{2}$ The acute complications of DM are diabetic ketoacidosis, non-ketotic hyperosmolar coma, and diabetic coma. The chronic complication is related to chronic elevation of blood sugar level which causes damage to blood vessels, ${ }^{3}$ and Dysfunction and failure of different organs, eyes, kidneys, nerves and heart. ${ }^{4}$ Currently available drugs for management of diabetes have certain disadvantages and thus there's a requirement to seek out safer and simpler antidiabetic drugs. ${ }^{5}$ The development mechanism of the discovery of antidiabetic drugs has changed its specialize in Plant-derived remedies because of their purity, effectiveness, cultural acceptability, and lesser side effect. ${ }^{6}$ Herbal source compounds are used since ancient times for diabetes treatment mellitus. About $90 \%$ of the world in rural areas, the population of for their primary health care, developing countries rely exclusively on conventional medicines. ${ }^{7}$

$\beta$-sitosterol may be a present plant sterol, ubiquitously found in many plants. ${ }^{8} \beta$ - sitosterol has been used as food additives in processed foods due to its nutraceutical advantages. It was shown that sitosterol is rich in margarine, ${ }^{9}$ butter, ${ }^{10}$ and orange juice. ${ }^{11}$ It was stated that $\beta$-Sitosterol has many biological activities such as anticancer, ${ }^{12}$ antioxidant, ${ }^{13}$ anti-inflammatory, ${ }^{14}$ chemoprotective / chemopreventive, ${ }^{15}$ hypocholesterolemic, ${ }^{16}$ neuroprotective $^{18}$ and It may be used for coronary artery disease therapy. ${ }^{19}$ benign prostatic hyperplasia $^{20}$ and diabetes. ${ }^{21}$ Many Studies have documented the antidiabetic activity of $\beta$-sitosterol. ${ }^{21,22}$ We have been studying the impact of $\beta$-sitosterol on post-receptor insulin signaling molecules and in silico analysis of adipose tissue, were also performed to seek out the binding affinity of $\beta$-sitosterol with insulin downstream signaling molecules. ${ }^{23,24}$ Even so, there are no studies available on the anti-diabetic effects of $\beta$-sitosterol on skeletal muscles. However, the mechanisms underlying the antidiabetic property of $\beta$-sitosterol on transduction of the insulin signal and oxidation of glucose is essentially unknown. Therefore, the current study is aimed to clarify the role of $\beta$-sitosterol in signaling molecules for insulin and glucose oxidation within high fat-diet induced type 2 diabetic experimental animals with gastrocnemius muscle.

\section{MATERIALS AND METHODS}

\section{Chemicals}

The molecular and analytical grades of all chemicals and reagents used in this analysis were purchased from Sigma
Chemical Company, St. Louis, MO, USA; Amersham Biosciences, Little Chalfont, Buckinghamshire, United Kingdom; MP Biomedicals, Santa Ana, CA 92707 USA; and Sisco Research Laboratories, Mumbai, India. ACON Laboratories, Inc. has purchased On-Call Plus Blood glucose test strips. San Diego, United States. $\beta$-sitosterol and $\beta$-actin actin monoclonal antibody were procured from Sigma Chemicals Company, USA. ${ }^{14} \mathrm{C}$-glucose and ${ }^{14} \mathrm{C}$-2-deoxyglucose were bought from the Radiation Board and Isotope Technology (BRIT), Mumbai, India. Crystal Chem Inc., USA, obtained the Ultra-sensitive rat insulin enzyme-linked immunosorbent assay (ELISA) package. In the present research, biochemical kits used were procured from Spinreact (Girona, Spain). Polyclonal IR- $\beta$, and GLUT4 antibodies were procured from Santa Cruz Biotechnology (USA).

\section{Animals}

Animals have been maintained in compliance with the National Principles and Specifications accepted by the Institutional Animal Ethics committee (IAEC No: 011/2016, dated 2016-07-04). In this study, healthy adult male Wistar strain (Rattus norvegicus) albino rats (150-180 days old, weighing 180-200g) were used and maintained in clean polypropylene cages at the Meenakshi Medical College and Research Institute (Meenakhsi Academy of Higher Education and Research) Central Animal House) under specific humidity $(65 \pm 5 \%)$ and temperature $\left(21 \pm 2^{\circ} \mathrm{C}\right)$ with constant $12 \mathrm{~h}$ light and $12 \mathrm{~h}$ dark schedule. They were fed with a normal rat pellet diet (Lipton India, Mumbai, India) and ad libitum was made available for clean drinking water.

\section{Induction of type-2 diabetes}

Rats were subjected to a high-fat diet of 60 days containing 3 percent cholesterol, 1 percent cholic acid, 30 percent coconut oil, and 66 percent and 30 percent sucrose through drinking water. On the $58^{\text {th }}$ day of treatment, blood glucose and rats were tested after overnight fasting. Which have blood glucose above $120 \mathrm{mg} / \mathrm{dl}$ were chosen as type-2 diabetic rats. Sucrose feeding through drinking water with high fat diet was continued until end of the study.

\section{Dose dependent study}

The optimum dose of beta-sitosterol sitosterol was calculated on the basis of the dose fixation analysis below. Rats were split randomly into following groups of 3 rats each. Group I: control (vehicle treated), Group II: rats were made diabetic (type 2 ) after 60 days of feeding by drinking water with a high fat diet and sucrose. $(30 \%)$. Group III-VIII: Diabetic (type-2) rats treated with beta sitosterol $(5,10,20$ and $30 \mathrm{mg} / \mathrm{kg}$ body weight/day, 
orally for 30 days, respectively). At the end of 30 days of treatment, the control and experimental animals were subjected to overnight fasting. Blood was extracted from the tip of the tail of the rat and blood glucose was tested using blood glucose test strips. From On-Call Plus. The outcomes are expressed as $\mathrm{mg} / \mathrm{dl}$. The dose of $\beta$ - sitosterol was fixed on the basis of reduction in the fasting blood glucose level. $\beta$-sitosterol at the doses of 10 and $20 \mathrm{mg}$ groups compared with regulation, it showed a substantial decrease in blood glucose. Markers of liver function (alanine transaminase, aspartate transaminase, and alkaline phosphatase) and markers of renal function (urea and creatinine) were measured for assessment of toxicity. No toxicity was found in 20 and $30 \mathrm{mg} \beta$-sitosterol treated animals. Since blood glucose was restored to normal range at $20 \mathrm{mg}$ dose itself, the same dose was selected for the present study.

\section{Experimental design}

Adult male albino rats of Wistar strain 150-180 days old with 180-200g body weight randomly, they were divided into five groups of 6 rats each.

\begin{tabular}{|c|c|}
\hline Group I & Normal rats \\
\hline Group II & Type-2 diabetic rats \\
\hline Group III & $\begin{array}{c}\text { Type-2 diabetic rat treated with SIT (20 mg/kg b.wt/ } \\
\text { day, orally for 30 days }\end{array}$ \\
\hline Group IV & $\begin{array}{c}\text { Type-2 Diabetic rats treated with metformin }(50 \mathrm{mg} / \\
\mathrm{kg} \text {, b.wt/day orally, for } 30 \text { days) }\end{array}$ \\
\hline Group V & $\begin{array}{r}\text { Normal rats treated with SIT (20mg/kg b.wt/day } \\
\text { orally, for 30 days) }\end{array}$ \\
\hline
\end{tabular}

Oral glucose tolerance (OGT) and insulin tolerance (ITT) tests were conducted on control and experimental animals two days before the killing. At the end of the experiment, the animals were anaesthetized with sodium thiopentone (40 $\mathrm{mg} / \mathrm{kg}$ body weight), blood was obtained by cardiac puncture, serum was isolated and stored at $-80^{\circ} \mathrm{C}$, and to clear the blood from the lungs, $20 \mathrm{ml}$ of isotonic sodium chloride solution was perfused through the left ventricle. Liver, gastrocnemius muscle and adipose tissues were dissected immediately and used for the different parameters.

\section{Fasting blood glucose (FBG)}

Blood glucose was estimated after overnight fasting using On-Call Plus blood glucose test strips (ACON Laboratories Inc., USA). By nicking the tip of the rat tail, blood has been obtained and findings are expressed as $\mathrm{mg} / \mathrm{dl}$.

\section{Oral Glucose Tolerance Test (OGTT)}

For oral glucose tolerance test, animals were fasted overnight and On-Call Plus blood glucose test strips for different periods of time were used to estimate blood glucose. (60, 120 and $180 \mathrm{~min}$ ) after giving the oral glucose load $(10 \mathrm{ml} / \mathrm{kg} ; 50 \% \mathrm{w} / \mathrm{v})$. Blood glucose value before giving glucose load is considered as $0 \mathrm{~min}$ value. Results are expressed as $\mathrm{mg} / \mathrm{dl}$.

\section{Insulin Tolerance Test (ITT)}

This test was performed on random-fed rats. Rats were injected with insulin $(0.75 \mathrm{U} / \mathrm{kg})$ in $\sim 0.1 \mathrm{ml} 0.9 \%$ saline intraperitoneally. A drop of blood $(5 \mu \mathrm{l})$ was taken from the tail vein prior to insulin injection and after 15, 30, 45, and $60 \mathrm{~min}$ for glucometer-based blood glucose determination. Results are expressed as $\mathrm{mg} / \mathrm{dl}$.

\section{Fasting serum insulin}

Serum insulin was tested using Crystal Chem Inc's ultrasensitive rat insulin ELISA kit (Illinois, USA). The detection range is $0.1-64 \mathrm{ng} / \mathrm{ml}$. The percentage of insulin antibody cross-reactivity to rat insulin was 100 percent. The coefficient of variation in the intra-assay was about $10.0 \%$ and the coefficient of variation in the inter-assay was about $10.0 \%$. Results are expressed in terms of $\mathrm{ng} / \mathrm{ml}$.

\section{Serum testosterone}

Serum testosterone was assayed using testosterone ELISA kit (DBC Diagnostics biochem, Canada). The testosterone concentration in the sample was calculated using standard graph and the results are expressed as $\mathrm{ng} / \mathrm{ml}$.

\section{Homeostasis Model Assessment for Insulin Resistance (HOMA-IR) and Quantitative Insulin Sensitivity Check Index (QUICKI)}

HOMA-IR was calculate using the formula (fasting blood glucose X fasting serum insulin/405) as per the method of Matthews et al. (1985) 25 and QUICKI was calculated using the formula 1/ (log fasting serum insulin $+\log$ fasting blood glucose) as per the method of Katz et al. (2000). ${ }^{26}$

\section{Serum lipid profile}

Serum cholesterol (CHO), triglyceride (TG), low-density lipoproteins (LDL), High-density lipoproteins (HDL) and free fatty acid (FFA) were assessed using assay kits purchased from Spinreact, Spain. Results for same are expressed as $\mathrm{mg} / \mathrm{dl}$.

\section{Liver and kidney function markers}

Markers of liver function (aspartate transaminase, alanine transaminase and phosphatase alkaline) and markers 
of kidney function (urea, creatinine and bilirubin) were measured using biochemical-assay kits procured from Spinreact, Spain. Results for same are expressed as U/L.

\section{Reactive oxygen species and lipid peroxidation}

Lipid peroxidation (LPO) was calculated by the technique of Tarachand and Devasagayam, (1987). ${ }^{27}$ The malondialdehyde content of the sample is expressed as protein-formed MDA nmoles $/ \mathrm{min} / \mathrm{mg}$. Hydrogen peroxide generation was assessed by the Pick and Keisari spectrophotometric process $(1981)^{28}$ and expressed as $\mu \mathrm{moles} / \mathrm{min} / \mathrm{mg}$ protein. Hydroxyl radical $\left(\mathrm{OH}^{*}\right)$ development was quantified by Puntarulo and Cederbaum $(1988)^{29}$ and expressed as $\mu$ moles $/ \mathrm{min} / \mathrm{mg}$ protein.

\section{Antioxidant enzymes}

Superoxide dismutase (SOD) was assessed by the method of Marklund, Marklund (1974) ${ }^{30}$ and the results expressed units/mg protein. Catalase activity (CAT) was assessed as per the method of Sinha $(1972)^{31}$ and the results for which are expressed as units/mg protein. Glutathione peroxidase (GPx) levels were assessed by method of Rotruck et al. (1973) $)^{32}$ and the activity were expressed as $\mu \mathrm{g}$ of glutathione utilized $/ \mathrm{min} / \mathrm{mg}$ protein. Glutathione-S-transferase (GST) activity was assessed by Habig et al. (1974) ${ }^{33}$ Results for the activities of GST are conveyed as $\mu$ moles of CDNB utilized $/ \mathrm{min} /$ $\mathrm{mg}$ protein. Glutathione reductase (GR) was assessed method of Staal et al. (1969) $)^{34}$ and reduced glutathione (GSH) levels were measure by the method of Moron et al. (1979) ${ }^{35}$ Results for the activity of GR and GSH are explained as nmoles of GSSG reduced $/ \mathrm{min} / \mathrm{mg}$ protein and nmoles of $\mathrm{GSH} / \mathrm{mg}$ protein respectively.

\section{${ }^{14} \mathrm{C}$-2-deoxyglucose uptake}

The uptake of glucose was estimated using ${ }^{14} \mathrm{C}-2$ dexoyglucose as per the method of Nevado et al. (2006). ${ }^{36}$ Results are expressed as CPM of ${ }^{14} \mathrm{C}-\mathrm{DOG}$ uptake $/ 100 \mathrm{mg}$ tissue.

\section{${ }^{14} \mathrm{C}$-glucose oxidation}

Glucose oxidation was estimated using ${ }^{14} \mathrm{C}$-glucose as per the method of Muthusamy et al. (2007). ${ }^{37}$ Results are expressed as $\mathrm{CPM}$ of ${ }^{14} \mathrm{CO}_{2}$ released/100 $\mathrm{mg}$ tissue.

\section{Tissue Glycogen}

Glycogen was measured by the process of Hassid and Abraham (1957) $\cdot^{38}$ Results for the amount of glycogen concentration are illustrated as $\mathrm{mg} / \mathrm{g}$ wet tissue.

\section{Protein expression analysis}

\section{Protein isolation}

The tissues were homogenized in buffer-A containing $10 \mathrm{mM} \mathrm{NaHCO}_{3}, 0.25 \mathrm{M}_{\text {sucrose, }} 5 \mathrm{mM} \mathrm{NaN}_{3}(1 \mathrm{ml}$ for $100 \mathrm{mg}$ ) At $1300 \mathrm{xg}$ for $10 \mathrm{~min}$ at $4^{\circ} \mathrm{C}$, the homogenate was centrifuged. The supernatant was centrifuged at $12,000 \mathrm{x}$ for $15 \mathrm{~min}$ at $4^{\circ} \mathrm{C}$. For insulin receptor study, the resultant supernatant was sampled as a complete protein (IR). For GLUT4 Western blot, protein measurement fractions of the cytosolic and plasma membrane were separated according to the process of Dombrowski et al. (1996) ${ }^{39}$ and Nevado et al. (2006). ${ }^{36}$ The protein concentration was estimated by Lowry et al. $(1951)^{40}$ using BSA (Bovine Serum Albumin) as a standard.

\section{Western blot analysis}

The lysate proteins $(50 \mu \mathrm{g} /$ lane) sodium dodecyl sulfatepolyacrylamide gel electrophoresis $(10 \%$ gel) was isolated and transferred to the polyvinylidene difluoride (PVDF) membrane by electroblotting (Bio-Rad Laboratories Inc). With 5\% non-fat dry milk, the membranes were blocked and the primary antibodies were tested (1:1000 dilution). The membrane was then washed and incubated for $1 \mathrm{~h}$ with horseradish peroxidase-conjugated secondary antibodies against rabbit-anti-mouse or goat-antirabbit (dilution 1:10000) (GeNei, Bangalore, India). An improved chemiluminescence detection system has detected the relevant signals. (Thermo Fisher scientific Inc, USA). Using Chemidoc, the protein bands were captured and quantified by Bio-Rad Laboratories, CA's Quantity One image analysis method. The membranes were then incubated in a stripping buffer (Thermo Scientific, USA) and the membrane was reprobated using a $\beta$-actin antibody (1:5000). The current research utilized rat $\beta$-actin as the invariant power. Santa Curz Biotechnology, USA, purchased the main antibodies.

\section{Statistical analysis}

The data were subjected to statistical analysis using one-way variance analysis (ANOVA) and a multiple range test by Duncan to determine the importance of individual differences between using computer-based tools, control and care groups (Graph Pad Prism version 5). The importance was considered at the $p<0.05$ stage in Duncan's test.

\section{RESULTS}

\section{Dose-dependent effect of $\beta$-sitosterol on fasting blood glucose in type-2 diabetic adult male rat}

Figure 1 Shows the dose-dependent effect of $\beta$-sitosterol on fasting blood glucose of control and experimental animals. Diabetic animals showed elevated blood 


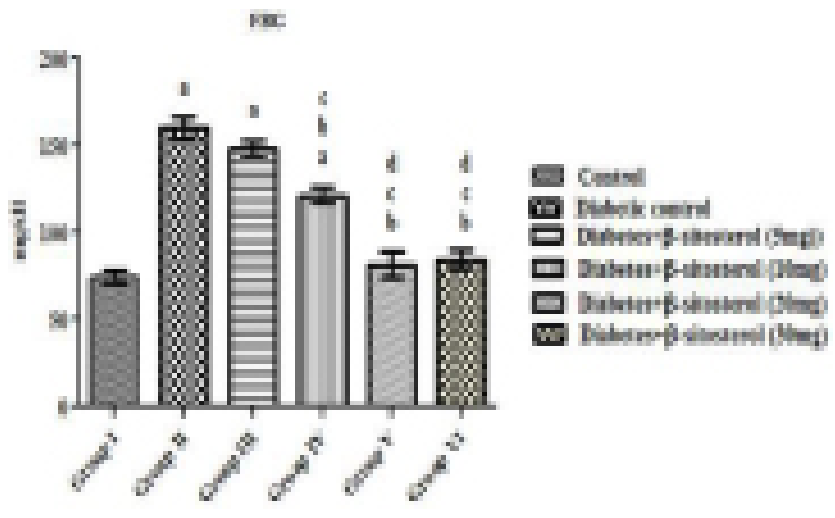

Figure 1: The dose dependent effect of $\beta$-sitosterol on fasting blood glucose of control and experimental animals.

Each value represents mean \pm SD of six animals. Significance at $p<0.05$, (a) compared with group-1 control; (b) compared with group-2 diabetic control; (c) compared with group-3 diabetes $+\beta$-sitosterol $(5 \mathrm{mg})$; (d) compared with group-4 diabetes + $\beta$-sitosterol (10mg).

glucose levels when compared to control. Treatment with 5 and $10 \mathrm{mg} / \mathrm{kg}$ b.wt $\beta$-sitosterol did not reach the control level. Whereas, 20 and $30 \mathrm{mg} / \mathrm{kg}$ b.wt doses effectively reduced the blood glucose levels in diabetic animals. Liver function markers (alanine transaminase, aspartate transaminase, and alkaline phosphatase) and kidney function markers (urea and creatinine) were found to be elevated in diabetic animals. $\beta$ sitosterol effectively reduced it. No toxicity was found in 20 and $30 \mathrm{mg} \beta$-sitosterol treated animals. Since blood glucose was restored to the normal range at $20 \mathrm{mg}$ dose itself, the same dose was selected as the optimal dose for the present study.

\section{Effect of $\beta$-sitosterol on glucose tolerance and fasting blood glucose in type-2 diabetic adult male rat}

Figure 2. a, b Shows the level of fasting blood glucose and glucose tolerance of control and experimental animals. Diabetic rats showed higher blood glucose level after glucose load and reached maximum at $1 \mathrm{hr}$. It did not reach $120 \mathrm{mg} / \mathrm{dl}$ even after $2 \mathrm{hr}$ of glucose load indicating glucose intolerance. Treatment with $20 \mathrm{mg}$ $\beta$-sitosterol improved glucose tolerance as that of standard drug metformin. Elevated fasting blood glucose in diabetic animals was also found to be reduced by $\beta$-sitosterol administration similar to that of standard drug metformin. $\beta$-sitosterol treatment to control rats did not show any alteration in oral glucose tolerance and fasting blood glucose.

\section{Effect of $\beta$-sitosterol on insulin tolerance in the type-2 diabetic adult male rat}

The level of insulin tolerance on control and experimental rats are presented in Figure 3. When insulin load was
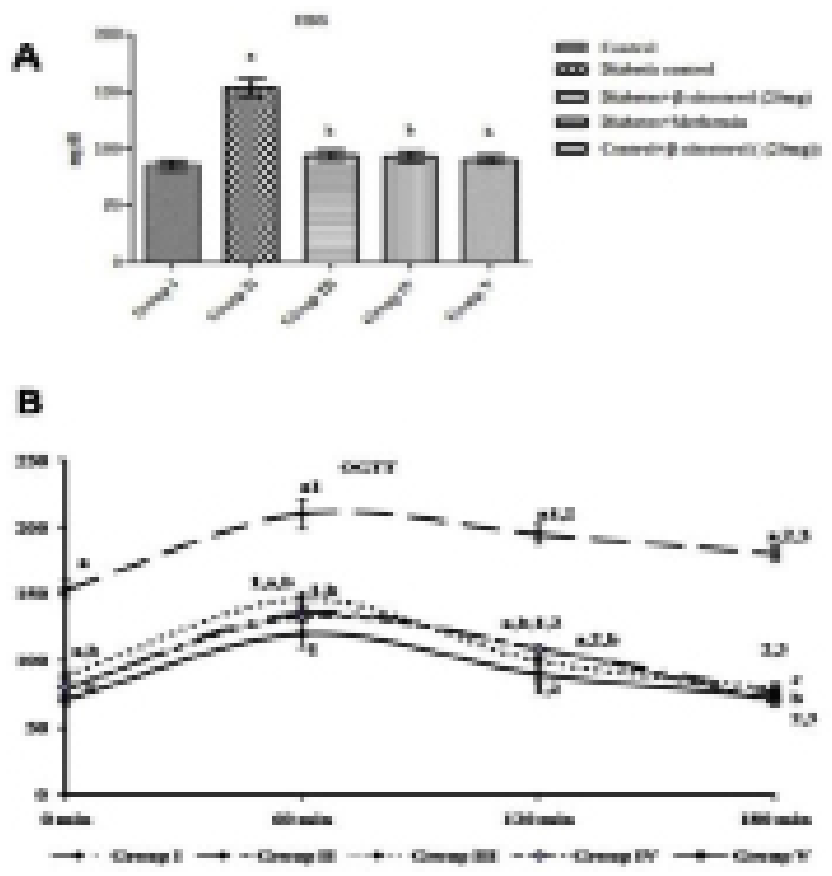

Figure 2: The effect of $\beta$-sitosterol on fasting blood glucose

(A) and Oral Glucose tolerance (OGT) of control and experimental animals.

Each bar/value is mean \pm SEM of six animals. Significance at $p<0.05$. a-compared with group-1 control, b-compared with group-2 diabetic control. 1-compared with respective fasting blood glucose, 2-compared with respective $1 \mathrm{hr}$ blood glucose, 3 -compared with respective $2 \mathrm{hr}$ blood glucose.

given to control rats, it shows a significant decrease and reached a minimum in $30 \mathrm{~min}$ and reached nearnormal range at $60 \mathrm{~min}$. Insulin administration to diabetic animals exhibits a slow decrement in blood glucose level and reaches the minimal level only at $60 \mathrm{~min}$ and it clearly shows impaired insulin tolerance. $\beta$-sitosterol treatment to diabetic animals improves insulin tolerance as that of standard drug metformin.

\section{Effect of $\beta$-sitosterol on serum insulin, HOMA-IR and QUICKI in type-2 diabetic adult male rat}

Figure $4 \mathrm{a}, \mathrm{b}$ represents the level of serum insulin, HOMA-IR, andQUICKIoncontrolandexperimental rats. The level of Fasting serum insulin was markedly increased in diabetic animals compared to control. $\beta$-sitosterol treatment to diabetic rats significantly reduced the insulin level. Control rats treated with $\beta$-sitosterol did not show any significant change. Insulin resistance and insulin sensitivity index values clearly suggest severe insulin resistance in diabetic animals. When compared to control, a significant increase in HOMA-IR and decrease in QUICKI values was observed in diabetic animals. Whereas, administration of $\beta$-sitosterol significantly altered these parameters to reach nearnormal range. Treatment with $\beta$-sitosterol to control 

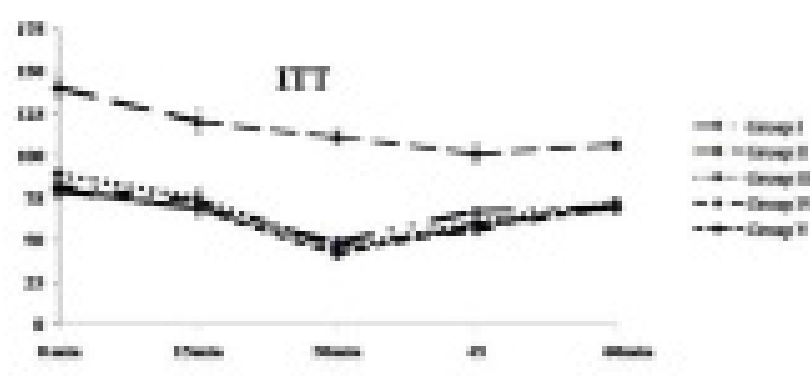

(1) - inimit

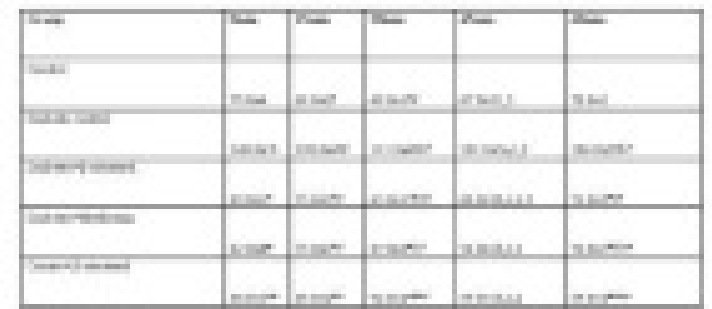

Figure 3: The level of insulin tolerance on control and experimental rats.

Each point/ value represents Mean \pm SEM of six animals. Significance at $p<0.05$, a- compared with group-1 control; b- compared with group-2 diabetic control; 1- compared with $0 \mathrm{~min}$ of respective group; 2 - compared with $15 \mathrm{~min}$ of respective group; 3- compared with 30 min of respective group; 4 - compared with 45 min of respective group.

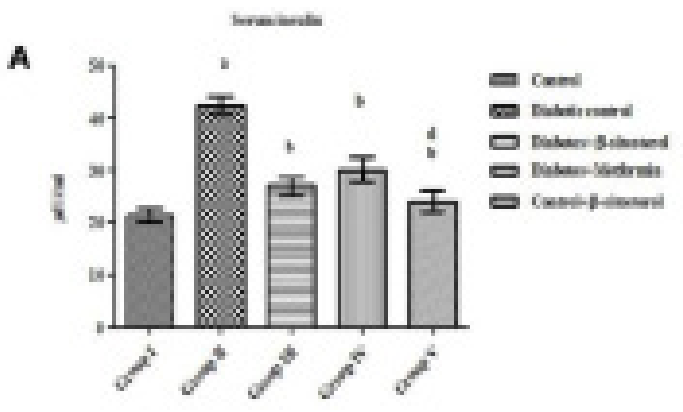

B

\begin{tabular}{|c|c|c|}
\hline$G \Rightarrow$ & meras & G०स \\
\hline Cones & & \\
\hline thetsendest & 19tרtยา & 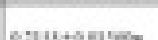 \\
\hline 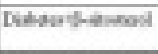 & antrobagit & ERsonasme \\
\hline Dedidervatime & 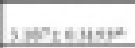 & testabsec \\
\hline crestidated & 2015+eters & 6romontamat \\
\hline
\end{tabular}

Figure 4: The level of serum insulin, HOMA and QUICKI on control and experimental rats.

Each bar represents Mean \pm SEM of six animals $(n=6)$ Significance at $p<0.05$. A-compared with group-1 control, b-compared with group-2 diabetic control. C-compared with group- 3 diabetes $+\beta$-sitosterol, d-compared with group-4 diabetes+metformin.

rats did not show any significant alteration compared to control.

\section{Effect of $\beta$-sitosterol on serum lipid profile in the} type-2 diabetic adult male rat
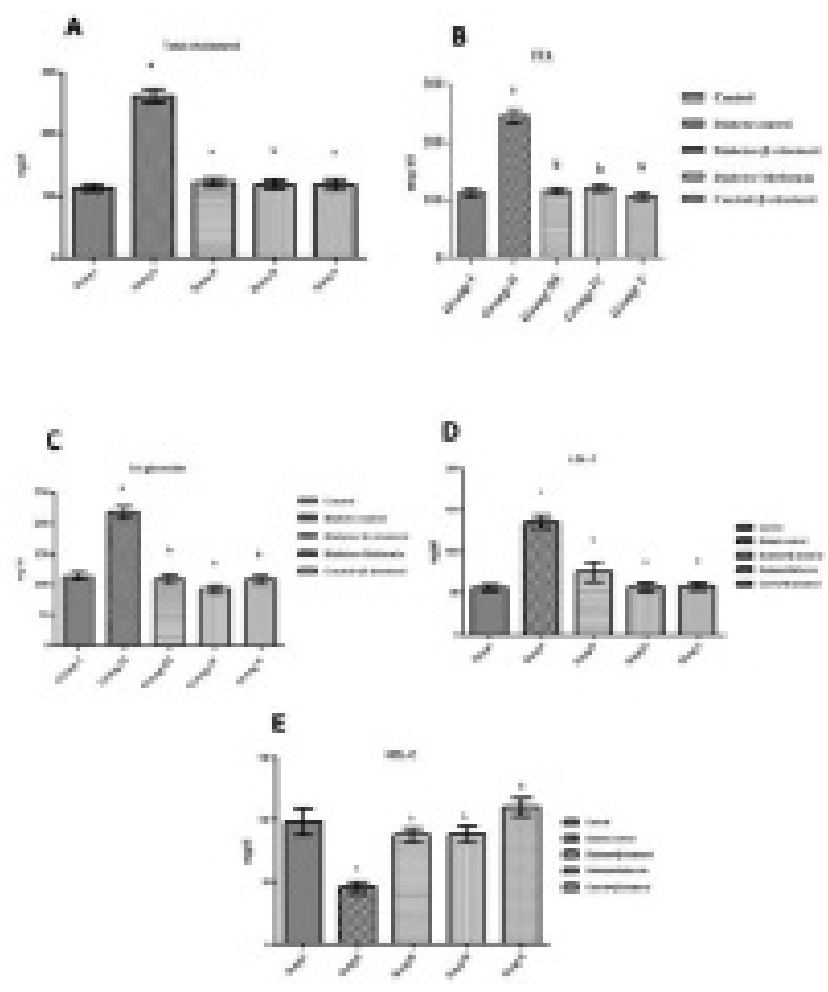

Figure 5: The level of total cholesterol (A), FFA (B), TG (C), LDL (D) and HDL (E) of control and experimental animals. Each bar represents Mean \pm SEM of six animals $(n=6)$ Significance at $p<0.05$. A-compared with Control, b-compared with group- 2 diabetic control.

The level of total cholesterol, FFA, TG, LDL, HDL of control, and experimental animals are represented in Figure 5a-e respectively. Increase level of Total cholesterol (TC), free fatty acid (FFA), triglyceride (TG) and LDL cholesterol (LDLC) but low HDL cholesterol (HDLC) was observed in diabetic animals. $\beta$-sitosterol alleviated dyslipidemia in par with that of metformin.

\section{Effect of $\beta$-sitosterol on ${ }^{14} \mathrm{C}$-2-deoxyglucose uptake and ${ }^{14} \mathrm{C}$-glucose oxidation in the gastrocnemius muscle}

Figure $6 \mathrm{a}, \mathrm{b}$ shows the level of glucose absorption and oxidation in control animals and in studies. In diabetic animals, glucose uptake and oxidation have been greatly reduced. $\beta$-sitosterol administration to diabetic animals improved the glucose uptake and oxidation in the gastrocnemius muscle as that of standard drug metformin. Control rats treated with $\beta$-sitosterol has no major improvement has been shown. When compared to control.

Effect of $\beta$-sitosterol on hydrogen peroxide $\left(\mathrm{H}_{2} \mathrm{O}_{2}\right)$, hydroxyl radical $\left({ }^{\circ} \mathrm{OH}\right)$ and lipid peroxidation (LPO) in the gastrocnemius muscle

Figure $7 \mathrm{a}-\mathrm{c}$ shows the level of hydrogen peroxide, hydroxyl radical and lipid peroxidation on control and 

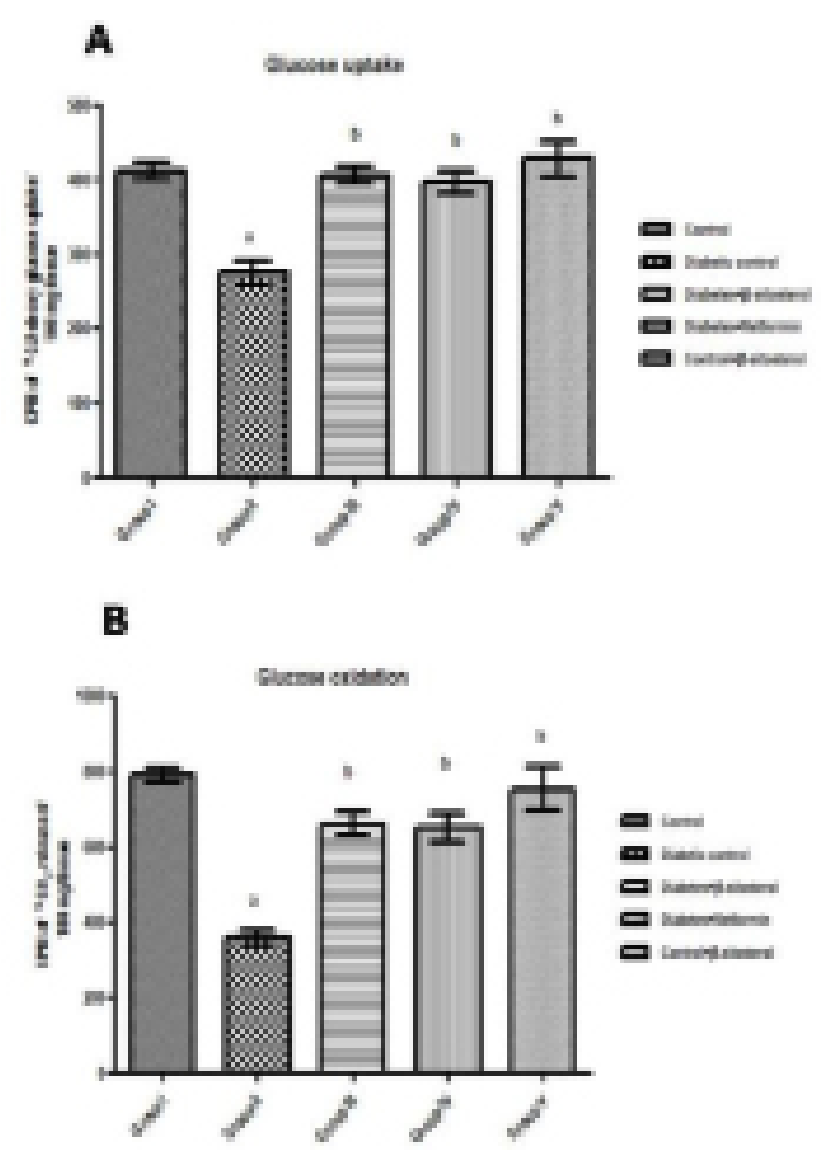

Figure 6: The effect of $\beta$-sitosterol on glucose uptake (A) and oxidation (B) on type 2 diabetic rats.

Mean \pm SEM of six animals $(n=6)$ Importance of each bar at $p<0.05$. A-in comparison with control, b-compared with group- 2 diabetic control.

experimental animals. Compared to control, the hydrogen peroxide $\left(\mathrm{H}_{2} \mathrm{O}_{2}\right)$, hydroxyl radical $\left({ }^{\circ} \mathrm{OH}\right)$, and lipid peroxidation (LPO) in gastrocnemius muscle of diabetic rats were significantly raised. $\beta$-sitosterol notably brought down the rise in hydrogen peroxide, hydroxyl radical, and lipid peroxidation.

\section{Effect of $\beta$-sitosterol on antioxidant enzymes in the gastrocnemius muscle}

Figure $8 \mathrm{a}-\mathrm{f}$ represents the level of superoxide dismutase, catalase, glutathione peroxidase, glutathione-S-transferase, glutathione reductase, and reduced glutathione in control and experimental rats. There was a marked decrease observed in superoxide dismutase, catalase, glutathione peroxidase, glutathione-S-transferase, glutathione reductase, and reduced glutathione in the gastrocnemius muscle of diabetic group compared to control. $\beta$-sitosterol efficiently increased the level of antioxidant enzymes compared to the diabetic group. Metformin showed a similar pattern to that of $\beta$-sitosterol. $\beta$-sitosterol treated control group did not indicate any change.
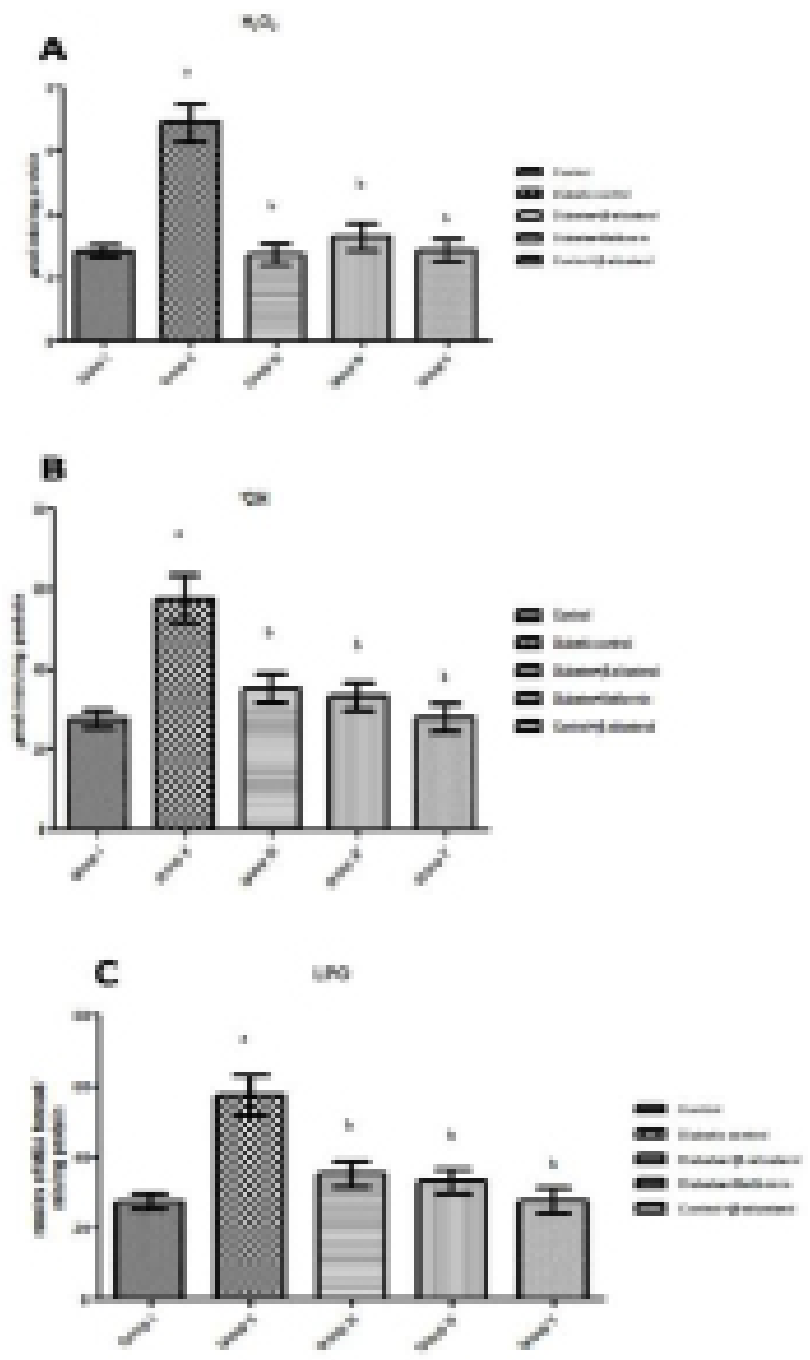

Figure 7: The level of hydrogen peroxide (A), hydroxyl radical (B) and lipid peroxidation (C) on control and experimental animals.

Each bar represents Mean \pm SEM of six animals $(n=6)$ Significance at $p<0.05$. a-compared with group- 1 control, b-compared with group-2 diabetic control.

\section{Effect of $\beta$-sitosterol on glycogen concentration in the gastrocnemius muscle}

Figure 9 shows the concentration of glycogen in control and experimental rats. Type- 2 diabetes significantly reduced gastrocnemius muscle glycogen concentration compared to control. $\beta$-sitosterol treatment partially restored this similar to that of metformin. There was no statistical significance observed between control rats and control rats treated with $\beta$-sitosterol.

\section{Effect of $\beta$-sitosterol on insulin receptor protein (IR) in the gastrocnemius muscle}

Figure 10 Shows the level of IR on control and experimental rats. A significant decrease $(p<0.05)$ in IR protein levels in gastrocnemius muscle was observed in type- 2 diabetic animals, whereas $\beta$-sitosterol treatment 

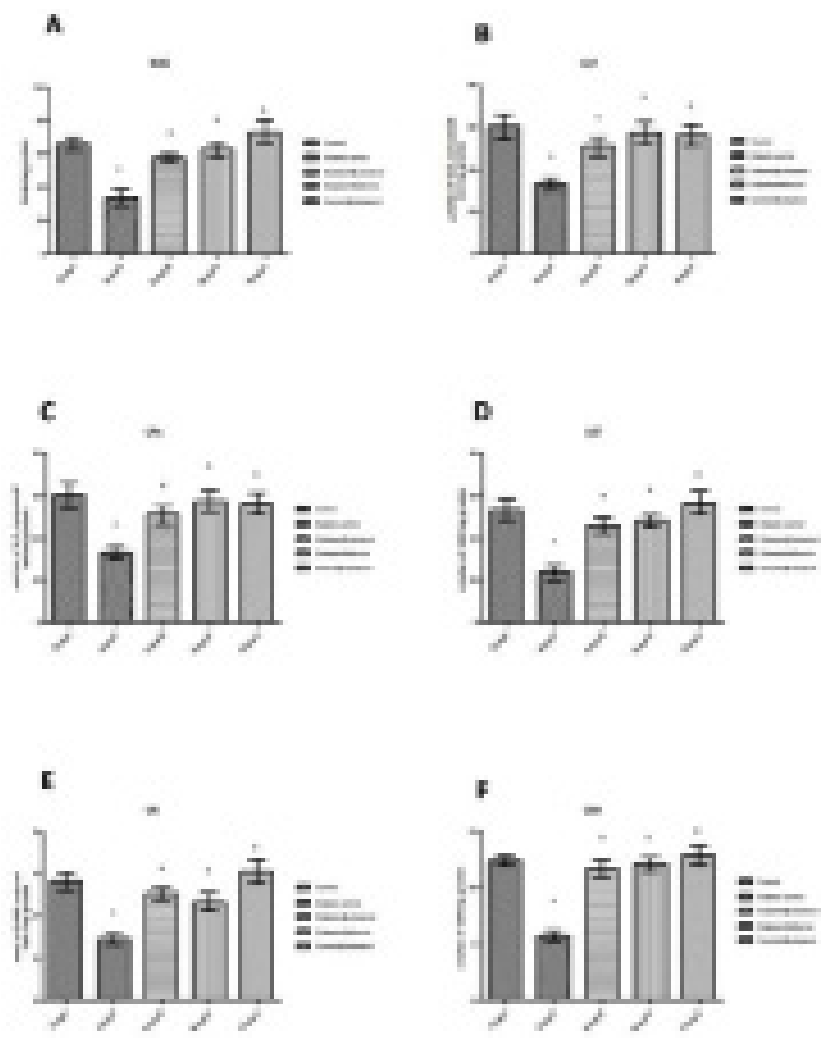

Figure 8: The level of superoxide dismutase (A), catalase (B), glutathione peroxidase (C), glutathione-S-transferase (D), glutathione reductase $(E)$ and reduced glutathione $(F)$ in control and experimental rats.

Each bar represents Mean \pm SEM of six animals $(n=6)$ Significance at $p<0.05$. a-compared with group-1 Control, b-compared with group- 2 diabetic control.

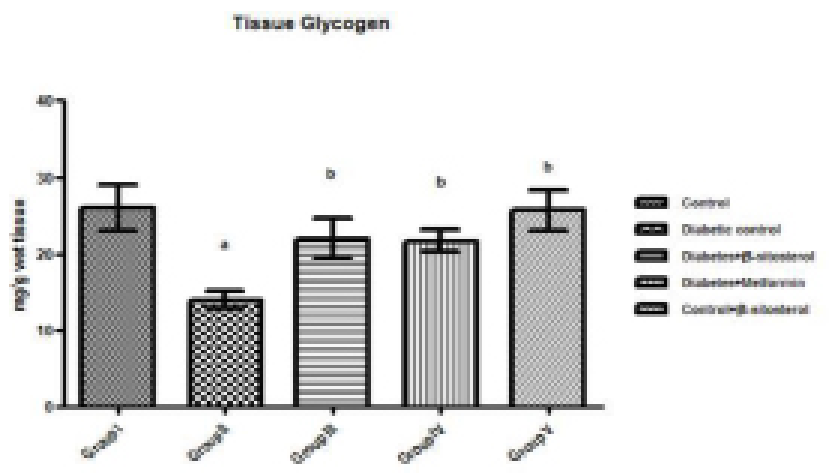

Figure 9: The concentration of glycogen in control and experimental rats.

Each bar represents Mean \pm SEM of six animals $(n=6)$ Significance at $p<0.05$. a-compared with group-1 Control, b-compared with group- 2 diabetic control.

increased the IR protein level in the type-2 diabetic animals. $\beta$-sitosterol treatment to control rats did not show any significant change in the IR protein level.

\section{Effect of $\beta$-sitosterol on glucose transporter 4 protein (GLUT4) in gastrocnemius muscle}

Figure 11 Shows the level of GLUT4 on control and experimental rats. In high fat diet-induced type-2

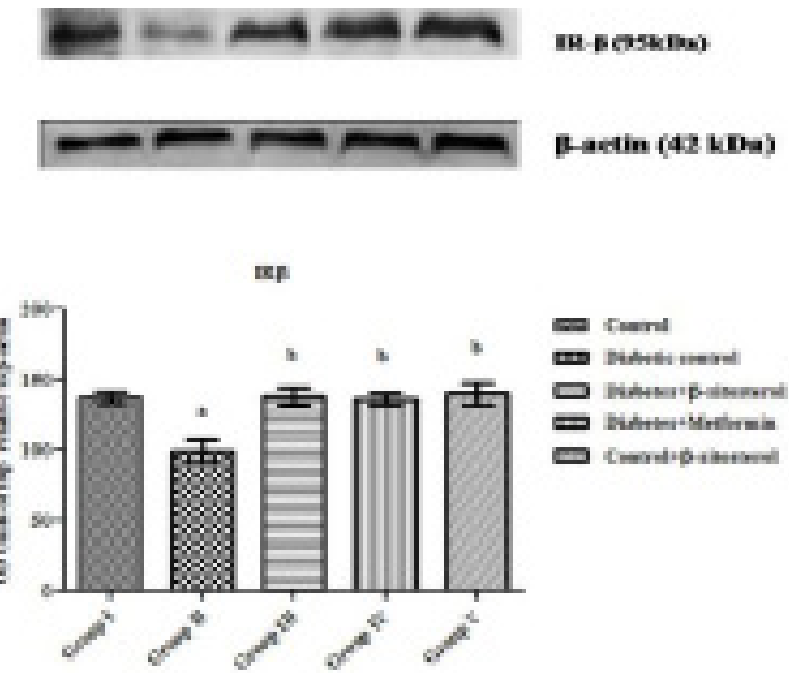

Figure 10: The level of insulin receptor on control and experimental rats.

Each bar represents Mean \pm SEM of three animals $(n=3)$ Significance at $p<0.05$.

A-compared with group-1 control, b-compared with group- 2 diabetic control.
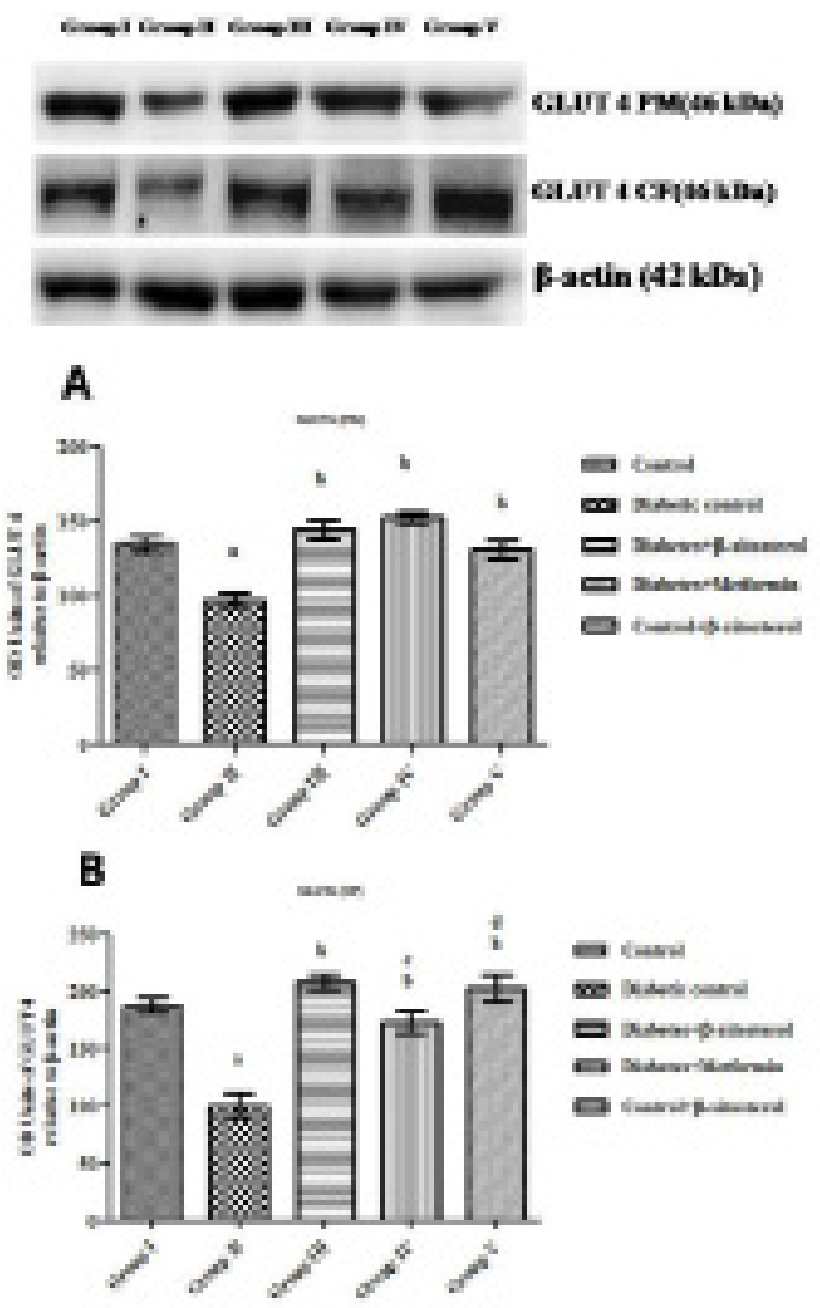

Figure 11: Shows the level of GLUT4 (PM) (A), GLUT4 (CF) (B) on control and experimental rats.

Each bar represents Mean \pm SEM of three animals $(n=3)$ Significance at $p<0.05$.

A-compared with group- 1 Control, b-compared with group- 2 diabetic control. 
diabetic rats, the levels of GLUT4 in the cytosol and its plasma membrane were found to be significantly reduced $(\phi<0.05)$ when compared to control animals. $\beta$-sitosterol treatment increased GLUT4 protein levels in type-2 diabetic animals. $\beta$-sitosterol treatment to control rats, no major improvement in the rats was seen in the GLUT4 protein levels.

\section{DISCUSSION}

Insulin resistance in skeletal muscle is a primary and important incident within the development of T2DM. ${ }^{41}$ Up to $85 \%$ of entire-body insulin-stimulated glucose uptake occurs in skeletal muscle and it is mediated by the translocation of glucose transporter molecules, mainly glucose transporter-4 (GLUT4) from endoplasmic reticulum to the plasma membrane. ${ }^{42,43}$ Many intracellular signaling cascades are involved in the translocation of GLUT4 vesicles including phosphorylation of insulin receptor substrate (IRS) molecules, phosphatidylinositol-3- kinase and protein kinase B (or) Akt. ${ }^{44}$ Within the present study, A large rise in body weight was seen when fed a high-fat diet. due to highfat diet induction, on the opposite hand, treatment with $\beta$-sitosterol, body weight has substantially decreased significantly due to potential hypocholesterolemic effect. Rats fed with a high-fat diet showed higher FBG and fasting serum insulin levels due to insulin resistance induced hyperglycemia. Conversely the decreased levels of FBG and insulin, increase in this study may be due to an increase in insulin sensitivity and IR mediated increase in glucose uptake and oxidation by $\beta$-sitosterol. The most common metabolic disorder associated with diabetes is hypertriglyceridemia and hypercholesterolemia. ${ }^{45,46}$ within the present investigation, the marked increase in total cholesterol, FFA, triglycerides, VLDL, LDL, and decreased HDL cholesterol levels were observed in high fat-fed diabetic rats. Excess fat intake results in dyslipidemia, which is related to elevated levels of FFAs, TG, and altered lipoprotein profile. Additionally, excess TG, FFA, and their metabolites can interfere with the activation of insulin-stimulated phosphatidylinositol-3-kinase (PI3K)/Akt and thereby lower the downstream signaling events of insulin, resulting in insulin resistance. ${ }^{47}$ Within the present study, the administration of $\beta$-sitosterol to high-fat diet-induced diabetic rats significantly decreased total cholesterol, FFA, triglycerides, VLDL, LDL, and significantly increased HDL cholesterol level. The hypocholesterolemic effect of $\beta$-Sitosterol is due to the inhibition of absorption of cholesterol in the intestine through competition with LDL-cholesterol. ${ }^{48}$
The increased formation of oxidative stress during cause of diabetes is an imbalance between the assembly of ROS and their elimination by antioxidants defense systems. ${ }^{49}$ Within the current investigation, the levels of antioxidants like SOD, CAT, GPx, GR and GSH were found to be substantially reduced in skeletal muscle of diabetes-induced rats. In addition, gastrocnemius the muscle of diabetic rats, treated with $\beta$-sitosterol showed a significantincrease within the levels of those antioxidants. Diabetic rats showed a rise in the number of rats in the current study, $\mathrm{H}_{2} \mathrm{O}_{2},{ }^{\circ} \mathrm{OH}, \mathrm{LPO}$, levels in the gastrocnemius muscle. $\beta$-sitosterol is a known antioxidant, which might have scavenged the excess ROS produced from the high fat diet, improved the antioxidants and restored the cell function. ${ }^{24}$

The concentration of glycogen was significantly decreased in the skeletal muscle tissues of diabetesinduced rats in comparison with control rats. In sight of impairment in the process of glycogenesis as a result of diminished Akt phosphorylation at Thr308 which is an important event within the activation of glycogen synthase. ${ }^{50}$ Upon treatment with $\beta$-sitosterol the glycogen content was restored to the normal level.

Although, diabetic rats treated with $\beta$-sitosterol notably reduced the levels of the same. Insulin resistance in skeletal muscle is that the primary defect before the $\beta$-cell dysfunction and hyperglycemia. ${ }^{51}$ When insulin binds with its receptor (IR) it activates the receptor tyrosine kinase, which in turn phosphorylates and engages other IRS proteins. Tyrosine-phosphorylated IRS provides binding sites for phosphatidylinositol-3 kinase (PI3K), which, in turn, activates Akt/protein kinase B, leading to increased translocation of intracellular GLUT4 to the plasma membrane. The stimulation of the IRS-PI3K-Akt pathway facilitates glucose uptake by the skeletal muscle cells. ${ }^{52}$ Insulin mediated glucose transport is decreased in the skeletal muscle during insulin-resistant states such as obesity, hypertension, and type- 2 diabetes. This is due to impairment in the expression and functionality of the insulin signaling pathway. ${ }^{53}$

The high fat diet-fed animals showed significantly lowered insulin-stimulated tyrosine kinase activity per IR which is related to decreased autophosphorylation of the $\beta$ receptor subunit and the lower percentage of tyrosine-phosphorylated receptors. ${ }^{54}$ Moreover, the increased FFA which is formed during high-fat diet treatment inhibits IR gene expression and that results in a decreased amount of IR protein in the insulin target cells. ${ }^{50}$ The present study showed a significant decrease in the IR protein expression in the gastrocnemius muscle of diabetes-induced rats. $\beta$-sitosterol treated 
type 2 diabetic rats showed increased IR protein levels as a result of the hypolipidemic potential of $\beta$-sitosterol. The uptake of glucose in insulin-sensitive tissues, like skeletal muscle and adipose tissue is mediated by GLUT4 transporter. When insulin binds with its receptor, GLUT4 vesicles are translocated from the cytoplasm to the plasma membrane and mediate glucose uptake by cells. The resistance to insulin in type 2 diabetes is because of decreased translocation of GLUT4. ${ }^{55,56}$ In our study, diabetes-induced rats showed a significant decrease in the GLUT4 protein expression in both the plasma membrane and cytosolic fractions. The increased FFA levels during type-2 diabetes may reduce the expression and translocation of GLUT4 from cytosol to the plasma membrane. ${ }^{57}$ In human cardiac muscle biopsies, expression of the GLUT4 promoter in cardiomyocytes and GLUT4 protein decreased under elevated FFA and lipotoxicity conditions, which also attenuated the Insulin signalling and GLUT4 translocation by IkB kinase (IKK) pathway activation. ${ }^{55}$ However $\beta$-sitosterol treated diabetic rats increase the GLUT4 levels in both plasma membrane and cytosol may be due to $\beta$-sitosterol mediated increase in insulin signaling molecule (IR). This study clearly shows the antidiabetic potential of $\beta$-sitosterol.

High fat diet-fed rats showed impairment in glucose uptake and oxidation. This is due to a decreased level of GLUT4 in the plasma membrane as results of decreased glucose uptake and oxidation which can be liable for the elevated blood glucose in diabetic rats. ${ }^{58}$ Treatment with $\beta$-sitosterol significantly increased glucose uptake and oxidation. This might be a consequence of $\beta$-sitosterol activated increased in insulin signaling molecule thereby increased GLUT4 translocation from cytosol to the plasma membrane.

\section{CONCLUSION}

$\beta$-sitosterol restores hyperglycemia and reduces the Type-2 Diabetes associated complications through the activation of insulin receptor molecules and increased translocation of GLUT4 within the skeletal muscle of high fat and sucrose induced type- 2 diabetic rats. Further, the potential of $\beta$-sitosterol on the expression of other insulin signaling molecules like IRS-1, IRS-2, Akt is required to be studied to elucidate the antidiabetic effect of $\beta$-sitosterol in detail. As of now it can be concluded that $\beta$-sitosterol may be a promising antidiabetic drug for the management of type $2 \mathrm{DM}$.

\section{ACKNOWLEDGEMENT}

The authors would like to thank, the professor and head, Department of Endocrinology, University of Madras,
Taramani Campus, Chennai-600113 for providing radio isotope laboratory facility for the assessment of ${ }^{14} \mathrm{C}-2$ deoxyglucose uptake and ${ }^{14} \mathrm{C}$-glucose oxidation assays.

\section{CONFLICT OF INTEREST}

The authors declare no conflicts of interest.

\section{Source of Funding}

This work was supported by the Department Of Science And Technology-Science and Engineering Research Council (ECR/2016/000415), the Engineering Research Board (DST-SERB) is highly recognized.

\section{ABBREVIATIONS}

HFD: High fat diet; FBG: Fasting blood sugar; OGT: Oralglucose tolerance;IT:Insulin tolerance;HOMA-IR: Homeostasis Model Assessment for Insulin Resistance; QUICKI: Quantitative Insulin Sensitivity Check Index; LPO: Lipid peroxidation; $\mathbf{H}_{2} \mathbf{O}_{2}$ : Hydrogen peroxide; OH: Hydroxyl radical; GLUT4: Glucose transporter subtype 4 .

\section{REFERENCES}

1. Hahm SW, Park J, Son YS. Opuntia humifusa stems lower blood glucose and cholesterol levels in streptozotocin-induced diabetic rats. Nutrition Research. 2011;31(6):479-87.

2. IDF Diabetes Atlas - $8^{\text {th }}$ Edition. 2017.

3. Andrew JK. Diabetes Churchill living stone New York. 2000.

4. Stuart C, Yudofsky REH. Neuropsychiatry and behavioral neurosciences. (4 ${ }^{\text {th }}$ Edition) American Psychiatry Publishing USA 800. 2008.

5. Grover JK, Vats V, Rathi SS. Antihyperglycemic effect of Eugenia jambolana and Tinospora cordifolia in experimental diabetes and their effects on key metabolic enzymes involved in carbohydrate metabolism. J Ethnopharmacol. 2000;73(3):461-70.

6. Veerapur VP, Prabhakar KR, Thippeswamy BS, Bansal P, Srinivasan KK, Unnikrishnan MK. Antidiabetic effect of Dodonaea viscose (L). Lacq Aerial parts in high fructose-fed insulin resistant rats: A mechanism based study. Indian Journal of Experimental Biology. 2010;48(8):800-10.

7. Hassan Z, Yam MF, Ahmad M, Yusof AP. Antidiabetic properties and mechanism of action of Gynura procumbens water extract in streptozotocininduced diabetic rats. Molecules. 2010;15(12):9008-23.

8. Pegal $\mathrm{KH}$. The importance of sitosterol and sitosterolin in human and animal nutrition. S Afr J Sci. 1997;93:263-8.

9. Thompson GR, Grundy SM. History and Development of Plant Sterol and Stanol Esters for Cholesterol-Lowering Purposes. Am J Cardiol. 2005;96:3-9.

10. Nestel P, Cehun M, Pomeroy S, Abbey M, Weldon G. Cholesterol-lowering effects of plant sterol esters and nonesterified stanols in margarine, butter and low-fat foods. Eur J Clin Nutr. 2001;55:1084

11. Devaraj S, Jialal I, Vega LS. Plant Sterol-Fortified Orange Juice Effectively Lowers Cholesterol Levels in Mildly Hypercholesterolemic Healthy Individuals. Arterioscler Throm Vasc Biol. 2004;24:e25-8.

12. Awad AB, Downie AC, Fink CS. Inhibition of growth and stimulation of apoptosis by beta-sitosterol treatment of MDA-MB-231 human breast cancer cells in culture. Int J Mol Med. 2000;5(5):541-6.

13. Baskar AA, AINumair KS, Paulraj MG, Alsaif MA, AIMuamar M, Ignacimuthu S. $\beta$ - Sitosterol prevents lipid peroxidation and improves antioxidant status and histoarchitecture in rats with 1,2-dimethylhydrazine-induced colon cancer. J Med Food. 2012;15(4):335-43. 
14. Loizou S, Lekakis I, Chrousos GP, Moutsatsou P. Beta-sitosterol exhibits antiinflammatory activity in human aortic endothelial cells. Mol Nutr Food Res. 2010;54(4):551-8.

15. Ovesna Z, Vachalkova A, Horvathova K. Taraxasterol and beta-sitosterol: New naturally compounds with chemoprotective/chemopreventive effects. Neoplasma. 2004;51(6):407-14.

16. Sugano M, Morioka $\mathrm{H}$, Ikeda I. A comparison of hypocholesterolemic activity of betasitosterol and beta-sitostanol in rats. J Nutr. 1977;107(11):2011-9.

17. Choi S, Kim KW, Choi JS, Han ST, Park YI, Lee SK, et al. Angiogenic activity of beta-sitosterol in the ischaemia/reperfusion-damaged brain of Mongolian gerbil. Planta Med. 2002;68:330-5. PMID:11988857

18. Shi $C$, Wu F, Zhu X, Xu J. Incorporation of $\beta$-sitosterol into the membrane increases resistance to oxidative stress and lipid peroxidation via estrogen receptor-mediated PI3K/GSK3 $\beta$ signaling. Biochim Biophysic Acta. 2013;1830(3):2538-44.

19. Weizel A, Richter WO. Drug therapy of severe hypercholesterolemia. Eru J Med Res. 1997;2:265-9.

20. Wilt TJ, MacDonald R, Ishani A. Beta-sitosterol for the treatment of benign prostatic hyperplasia: A systematic review. BJU Int. 1999;83(9):976-83.

21. Gupta A, Sharma AK, Dobhal MP, Sharma MC, Gupta RS. Antidiabetic and antioxidant potential of b-sitosterol in treptozotocin-induced experimental hyperglycemia. J Diabetes. 2011;3(1):29-37.

22. Radika MK, Viswanathan $P$, Anuradha CV. Nitric oxide mediates the insulin sensitizing effects of b-sitosterol in high fat diet-fed rats. Nitric Oxide. 2013;32:43-53.

23. Ponnulakshmi R, Shyamaladevi B, Vijayalakshmi P, Selvaraj J. In silico and in vivo analysis to identify the antidiabetic activity of beta sitosterol in adipose tissue of high fat diet and sucrose induced type-2 diabetic experimental rats. Toxicology Mechanisms and Methods. 2018.

24. Babu S, Krishnan M, Rajagopal P, Periyasamy V, Veeraraghavan V, Govindan R, et al. Beta-sitosterol attenuates insulin resistance in adipose tissue via IRS-1/Akt mediated insulin signaling in high fat diet and sucrose induced type-2 diabetic rats. European Journal of Pharmacology. 2020;873:173004. doi: https://doi.org/10.1016/j.ejphar.2020.173004.

25. Matthews DR, Hosker JP, Rudenski AS, Naylor BA, Treacher DF, Turner RC Homeostasis model assessment: Insulin resistance and beta-cell function from fasting plasma glucose and insulin concentrations in man. Diabetologia. 1985;28(7):412-9.

26. Katz A, Nambi SS, Mather K, Baron AD, et al. Quantitative Insulin Sensitivity Check Index: A Simple, Accurate Method for Assessing Insulin Sensitivity In Humans. The Journal of Clinical Endocrinology and Metabolism. 2000;85(7):2402-10.

27. Devasagayam TP, Tarachand U. Decreased lipid peroxidation in rat kidneys during gestation. Biochem Biophys Res Commun. 1987;145(1):134-8.

28. Pick E, Keisari $\mathrm{Y}$. Superoxide anion and $\mathrm{H}_{2} \mathrm{O}_{2}$ production by chemically elicited peritoneal macrophages-induction by multiple nonphagocytic stimuli. Cell Immunol. 1981;59(2):301-18.

29. Puntarulo S, Cederbaum Al. Comparison of the ability of ferric complexes to catalyze microsomal chemiluminescence, lipid peroxidation, and hydroxyl radical generation. Arch Biochem Biophys. 1998;264(2):482-91.

30. Marklund S, Marklund G. Involvement of the superoxide anion radical in the autoxidation of pyrogallol and a convenient assay for superoxide dismutase. European Journal of Biochemistry. 1974;47(3):469-74.

31. Sinha AK. Colorimetric assay of catalase. Analytical Biochemistry. 1972;47(2):389-94.

32. Rotruck J, Pope A, Ganther H, Swanson A, et al. Selenium: Biochemical role as a component of glutathione peroxidase. Science. 1973;179(4073):588-90.

33. Habig W, Pabst M, Jakoby W. Glutathione S-transferases. The first enzymatic step in mercapturic acid formation. The Journal of Biological Chemistry. 1974;249(22):7130-9.

34. Staal GE, Visser J, Veeger C. Purification and properties of glutathione reductase of human erythrocytes. Biochimica et Biophysica Acta (BBA)Enzymology. 1969;185(1):39-48.

35. Moron MS, Depierre JW, Mannervik B. Levels of glutathione, glutathione reductase and glutathione S-transferase activities in rat lung and liver. Biochimica et Biophysica Acta (BBA)-General Subjects. 1979;582(1):67-78.

36. Nevado C, Valverde AM, Benito M. Role of insulin receptor in the regulation of glucose uptake in neonatal hepatocytes. Endocrinology. 2006;147(8):3709-18.
37. Muthusamy T, Dhevika S, Murugesan P, Balasubramanian K. Testosterone deficiency impairs glucose oxidation through defective insulin and its receptor gene expression in target tissues of adult male rats. Life Sciences. 2007;81(7):534-42.

38. Hassid WZ, Abraham S. Determination of glycogen with anthrone reagent. Methods Enzymol. 1975;3:34-7.

39. Dombrowski L, Roy D, Mareotte B, Marette A. A new procedure for the isolation of plasma membrane, T-tubules and internal membranes from skeletal muscles. Am J Physiol. 1996;270(4):E667-76.

40. Lowry O, Rosebrough N, Farr A, Randall R. Protein measurement with the Folin phenol reagent. The Journal of Biological Chemistry. 1951;193:265-75.

41. DeFronzo RA, Tripathy D. Skeletal muscle insulin resistance is the primary defect in type 2 diabetes. Diabetes Care. 2009;32(suppl 2):S157-63.

42. Klip A, Ishiki M. Recent developments in the regulation of glucose transporter-4 traffic: New signals, locations and partners. Endocrinology. 2005;146(12):5071-8.

43. Dhananjayan I, Shankar J, Jayaraman S, Sampath S, Chinnaiyan M, Narasimhan A, et al. Effect of bisphenol-A on insulin signal transduction and glucose oxidation in skeletal muscle of adult male albino rat. Human and Experimental Toxicology. 2012;32(9):1-12.

44. Saltiel AR, Kahn CR. Insulin signaling and the regulation of glucose and lipid metabolism. Nature. 2001;414(6865):799-806.

45. Khan BA, Abraham A, Leelamma S. Hypoglycemic action of Murraya koenigii (curry leaf), Brassica juncea (mustard); mechanism of action. Ind J Biochem Biophys. 1995;32(2):106-8.

46. Mitra SK, Gopumadhavan S, Muralidhar TS, Anturlikar SD, Sujatha MB. Effect of D-400, a herbomineral preparation on lipid profile, glycated hemoglobin and glucose tolerance in streptozotocin induced diabetes in rats. Ind J Exp Biol. 1995;33(10):798-800

47. Sheffield-Moore M, Urban RJ. An overview of the endocrinology of skeletal muscle. Trends Endocrinol Metab. 2004;15(3):110-5.

48. Gylling $\mathrm{H}$, Miettinen TA. Effects of inhibiting cholesterol absorption and synthesis on cholesterol and lipoprotein metabolism in hypercholesterolemic non-insulin-dependent diabetic men. J Lipid Res. 1996;37(8):1776-85.

49. Hong $\mathrm{JH}$, Lee IS. Effects of Artemisia capillaries ethyl acetate fraction on oxidative stress and antioxidant enzyme in high-fat diet induced obese mice. Chem Biol Interact. 2009;179(2-3):88-93.

50. Satyanarayana K, Sravanthi K, Shaker IA, Ponnulakshmi R, Selvaraj J. Studies on the role of chrysin on the expression of insulin signaling molecules in the gastrocnemius muscle of high-fat and sucrose-induced type-2 diabetic adult male rats. J Ayurveda Integr Med. 2014.

51. Henriksen EJ, Prasannarong M. The role of the rennin-angiotensin system in the development of insulin resistance in skeletal muscle. Mol Cell Endocrinol. 2013;378:15-22.

52. Erion DM, Shulman GI. Diacylglycerol-mediated Insulin resistance. Nat Med. 2010;16(4):400-2.

53. Anandhi R, Annadurai T, Anitha TS, Muralidharan AR, Najmunnisha K, Nachiappan V, et al. Antihypercholesterolemic and antioxidative effects of an extract of the oyster mushroom, pleurotusostreatus and its major constituent, chrysin, in triton WR-1339-induced hypercholesterolemic rats. J Physiol Biochem. 2013;69(2):313-23

54. Li Y, Soos TJ, Li X, Wu J, Degennaro M, Sun X, et al. Protein kinase C theta inhibits insulin signaling by phosphorylating IRS1 at Ser (1101). J Biol Chem. 2004;279(44):45304-7.

55. Cross DA, Alessi DR, Cohen P, Andjelkovich M, Hemmings BA. Inhibition of glycogen synthase kinase- 3 by insulin mediated by protein kinase $B$. Nature. 1995;378(6559):785-9.

56. Nie Y, Ma RC, Chan JC, Xu H, Xu G. Glucose-dependent insulinotropic peptide impairs insulin signaling via inducing adipocyte inflammation in glucose-dependent insulinotropic peptide receptor-overexpressing adipocytes. FASEB J. 2012;26(6):2383-93.

57. Balaji V, Williams AA, Sathish S, Mayilvanan C, Narasimhan A, Balasubramanian K. Antidiabetic potentials of a novel polyherbal preparation formulated according to principles of Siddha system of medicine. J Evid Based Complementary Altern Med. 2012;17(3):180-90.

58. Selvaraj J, Sathish S, Mayilvanan C, Balasubramanian K. Excess aldosterone-induced changes in insulin signaling molecules and glucose 

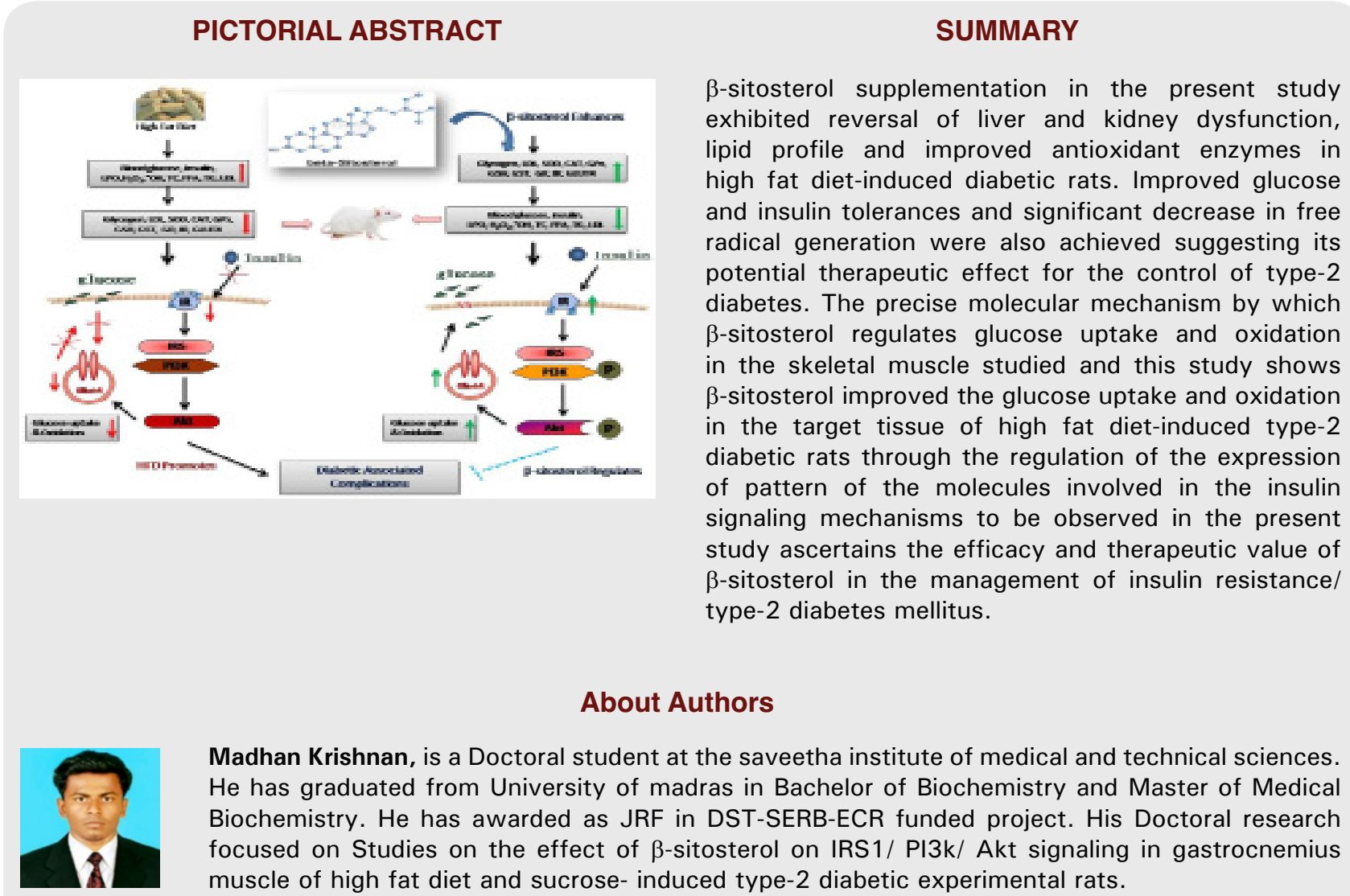

\begin{abstract}
About Authors
Madhan Krishnan, is a Doctoral student at the saveetha institute of medical and technical sciences. $\mathrm{He}$ has graduated from University of madras in Bachelor of Biochemistry and Master of Medical Biochemistry. He has awarded as JRF in DST-SERB-ECR funded project. His Doctoral research focused on Studies on the effect of $\beta$-sitosterol on IRS1/ PI3k/ Akt signaling in gastrocnemius muscle of high fat diet and sucrose- induced type-2 diabetic experimental rats.
\end{abstract}

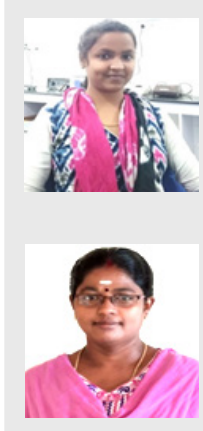

Shyamaladevi Babu, is a doctoral student at the saveetha institute of medical and technical sciences. She has graduated from University of madras in Bachelor of Biochemistry and Master of Biochemistry. She has Her Doctoral research focused on Molecular approach to identify the effect of $\beta$-sitosterol on insulin and inflammatory signaling molecules in adipose tissue of high fat diet and sucrose induced type-2 diabetic rats.

Dr. Ponnulakshmi Rajagopal, Research Scientist, Central Research Laboratory, Meenakshi Academy of Higher Education and Research (Deemed to be University), Chennai-600 077, India, has 10 years of Research and Teaching experience, working on molecular aspects of phytotherapeutic drugs in Diabetes and Cancer using experimental animal and Cell line models. She has published several research papers in reputed Journals and presented her findings in various National and International conferences. Currently she is guiding $3 \mathrm{Ph} . \mathrm{D}$ students and to her credit she is serving as active reviewer in reputed journal like Frontiers in Oncology, Molecular and Cellular Biochemistry, Meta Gene. Etc.

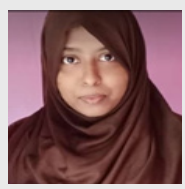

Sohara Parveen Nazar, is a tutor in the Department of Biochemistry, Faculty of Allied Health Sciences, Dr. M.G.R. Educational and Research Institute. She has graduated from University of madras in Bachelor of Biochemistry and Master of Medical Biochemistry. She has awarded as JRF in DST-SERB-ECR funded project and she has experience in phytochemical analysis and isolation of specific plant compounds.

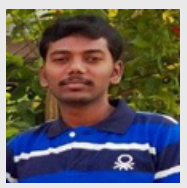

Dr. Mayilvanan Chinnayan, is a Post Doctoral Fellow in the Department of Otolaryngology, University of Oklahoma Health Sciences Center, Oklahoma City, USA. He did his Doctoral study in the Dept of Endocrinology, Institute of Basic Medical Sciences, University of Madras. 
Dr. Selvaraj Jayaraman, Endocrinologist, Associate Professor in the department of Biochemistry, Saveetha Dental College and Hospitals, SIMATS, Chennai-600 077, India has 12 years of research and teaching experience in Diabetology and Cancer. His research contributions have been appreciated by DST-SERB, Government India and Government of Tamil Nadu major research funded projects (Rs. 70 Lakh). He has published several research papers in journals of reputes and guiding $7 \mathrm{Ph}$.D. students. To his credit he is an active reviewer in indexed journals such as European journal of pharmacology, Journal of Ethano Pharmacology, Toxicology letters, Molecular and cellular biochemistry, Meta gene etc. To his credit, he has conducted several workshops and presented his findings in national and international seminar/symposia.

Cite this article: Krishnan M, Babu S, Rajagopal P, Nazar SP, Chinnaiyan M, Jayaraman S. Effect of $\beta$-sitosterol on Insulin Receptor, Glucose Transporter 4 Protein Expression and Glucose Oxidation in the Gastrocnemius Muscle of High Fat Diet Induced Type -2 Diabetic Experimental Rats. Indian J of Pharmaceutical Education and Research. $2021 ; 55(2 s): s 479-s 491$. 